\title{
Translation Testing in Idioms Translation of Fiction from English into Thai
}

\author{
Chinchira Bunchutrakun
}

\begin{abstract}
The purposes of the study are to revise the translated idioms of fictions which were translated from English into Thai and offer alternative ways to improve the translation by translation testing method. The translation testing was conducted with the translators and the researcher as a reviewer in order to assess their satisfaction with the translation work in terms of accuracy, clarity and naturalness.

The original English version and the Thai translated version of each of two works of fiction were purposively selected for the study. The first was Mr.Maybe, written by Jane Green and translated by Montharat Songphao. The second was The Trials of Tiffany Trott, written by Isabel Wolff and translated by Jitraporn Notoda. Thirty idioms of two translated works of fiction were, then, examined by the translators.

As a result of this testing process, the two translators found the translations of some idioms dissatisfactory and suggested alternatives, as did the researcher as a reviewer, in order to improve the translations.
\end{abstract}

Index Terms-Translation, idiom translation, fiction translation, translation testing.

\section{INTRODUCTION}

These days, communication technology breakthroughs make it possible to contact people who are far away [1]. As a result, translation plays more significant role due to this globalization where people communicate with one another from different background culture and languages. Consequently, translation of texts, fictions, magazines etc. are required to assist people to gain more understanding. This is the task of translation; for as Newmark [2] states, translation is a craft consisting in the attempt to replace a written message and/or statement in one language by the same message and/or statement in another language. The result of such a task is a work of translation.

There are various kinds of works of translation, such as news, movie subtitles, magazine articles, and books. Another branch of translation is the translation of fiction, and indeed this is a branch which has become more outstanding in the translation field. According to Kennedy [3], fiction is a term used to refer to a story that is not entirely factual, but, at least partially, shaped, made up or imagined. However, since fiction, though is at least sometimes partly imaginative, is still based on real life, its readers can easily appreciate it. As a result, its popularity is rising. Readers consume works of this genre of entertainment that were written not only in their own language but also those written in foreign languages. In

Manuscript received December 11, 2014; revised February 28, 2015.

Chinchira Bunchutrakun is with the Faculty of Humanities and Social Sciences at Suan Sunandha Rajabhat University, Bangkok, 10300 Thailand (e-mail: chinchira.bu@ssruac.th).
Thailand, English fiction is gaining popularity, and there are many of Thai translations of English fiction on the market nowadays.

The language in fiction is usually colloquial because it comprises both narratives and dialogues. In dialogues, particularly, there are a lot of words, phrases, sentences from the spoken language. This colloquial language often causes problems in translation, since it usually contains cultural meanings, secondary meanings or figurative meanings. As a result, it is difficult to find equivalents in the target language when translating from one language into another, especially, as Larson [4] states when the cultures of the languages are different.

Even though there are many theories and studies concerned with translation, there are few studies on fiction translation, and particularly on translation of idioms in fiction. Idioms are generally colloquial; therefore, they are interesting to study, especially concerning how they are translated. For example, sometimes they convey cultural meanings so the translator has to use his/her knowledge and skill of both languages and experience in translation in choosing the appropriate lexical equivalent. In this process, the translator plays an important role in solving problems and finding lexical equivalents. The translator needs to understand both the source language and the target language well in order to find the appropriate lexical equivalent. It can thus be seen that the translator is very significant since his/her responsibility is to decide how to translate the text.

\section{HYPOTHESIS}

Translating a single word often causes problems in some way; therefore, translating words that have figurative senses, such as idioms, might cause some difficulties as well. Since this research was conducted in a specific area of translation, there might be a question of the accuracy, clarity and naturalness of the translation work in the target language.

\section{PURPOSES OF THE STUDY}

The study was conducted to revise the translation text and offer alternative ways to improve the translation. In addition, it is to find the answer to the question "Are the translators satisfied with their translation in terms of their accuracy, clarity and naturalness in the target language?

\section{REVIEW OF LITERATURE}

\section{A. Definitions of Terms}

'Source language' (SL) refers to the original language of 
the text that has been translated. In this study, the source language is English.

'Target language' (TL) refers to the translated version of a text. In this study, the target language is Thai.

'Dialogue' refers to all the conversations of the characters in the book.

\section{B. Definitions of Idioms}

Larson [2] also defines an idiom as a dead metaphor, which means a metaphor that is used without the primary sense of its words being recognized; only the idiomatic sense of the word is directly recognized. In English, there are a lot of idioms like this, such as "run into debt", "the head of state" etc. Native speakers use these idioms and think directly of their meaning instead of the primary senses of the component words.

The Oxford English Dictionary (1989 cited in Fernando, 1996: 3-4) [5] defined an idiom as "a form of expression, grammatical construction, phrase etc., peculiar to a language; a peculiarity of phraseology approved by the usage of a language, and often having a significance other than its grammatical or logical one."

Fernando [5] divides idioms into three sub-classes: pure idioms, semi-idioms and literal idioms.

\section{1) Pure idioms}

A pure idiom is a type of conventionalized, non-literal multiword expression. For instance, the meaning of spill the beans has nothing to do with beans; its non-literal meaning is imposed on the idiom as a whole: commit an indiscretion.

\section{2) Semi-idioms}

A semi-idiom (Weinreich 1969; Cowie 1981 cited in Fernando 1996: 36) [5] has one or more literal constituents and at least one with a non-literal subsense, usually special to that co-occurrence relation and no other. 'Foot', for example, means 'pay' only when it occurs with bill as in 'foot the bill'.

\section{3) Literal idioms}

Literal idioms are less semantically complex than are pure and semi-idioms. The idioms must meet the criterion of either invariance or restricted variation. Some idioms that meet the criterion of invariance are, for example, "on foot," "arm in arm," "tall, dark and handsome," and "happy New Year." Some idioms that meet the criterion of restricted variation are "in order that/to," "for example/instance," "happy/merry Christmas," and "vise versa."

Based on the above definitions, it can be concluded that an idiom consists of at least two lexical items and is familiar to native speakers, but often cannot literally be understood by non-native speakers. This is because idiom is one class of figurative expression. Even though idioms are divided into three sub-classes, it is difficult to maintain the strict division among the three groups. In this study; therefore, the researcher will look at idioms as a whole: without classification. However, further studies on translating idioms in each sub-class are recommended.

\section{Testing the Translation}

According to Larson [4], the translator always wants his/her work of translation to be a good quality; therefore, testing the translation is important. It is sometimes done in an early stage of the translation process but sometimes after the work has been released. In testing the translation, three main features are of concern - accuracy, clarity and naturalness, for translators often make mistakes related to these features. Sometimes a translator has misunderstood the text and has translated it wrongly. Sometimes the translation work may be accurate, but does not communicate well with its readers, who are unfamiliar with the source text. Or sometimes the text is both accurate and clear, but it is unnatural to native speakers of the target language. Therefore, the translation work needed to be improved its accuracy, clarity and naturalness.

Testing translation can be done by the translators themselves, both during the translation process and after releasing the work of translation. It is very useful to have a translation consultant when doing a translation project because s/he can greatly help the translator by answering any questions that came up during the process. Another person who can help testing the translation is a tester. Testers are persons who take a draft of the translation work to other people and see if those people can understand the text clearly or not. In addition, a reviewer who is willing to read the translation work can also help testing the translation by making comments on the accuracy, clarity and naturalness.

\section{Methodology}

The original English version and the Thai translated version of each of two works of fiction were used for the study. These two works were written and translated by different persons. The first was Mr.Maybe, written by Jane Green [6]and translated by Montharat Songphao [7]. The second was The Trials of Tiffany Trott, written by Isabel Wolff [8] and translated by Jitraporn Notoda [9].

In order to select the material for the study, a purposive sampling was used based on the following rationale: the genre of the story which is a modern English romance fiction and the colloquial language.

The data were collected from the original versions of the two novels and their translated versions. In this research, the idioms were chosen on the condition that they were used in dialogue, since it was considered that idioms occur often in colloquial language and that colloquial language is the language of speech, which is represented in the dialogues of these romances. There were a large number of idioms met the criteria, but only 30 idioms from each book were selected for this study. Idioms that occurred repeatedly were firstly considered, and the rest were randomly chosen.

To analyze the data, thirty idioms from each book were presented to the translators of the books. The translators were then interviewed using with the first and the second parts of the questionnaire.

\section{RESULTS}

The answer to the question of whether the translators were satisfied with their translation of these works in terms of their accuracy, clarity and naturalness in the target language?

In this study, the translators were presented 30 idioms in order to assess their satisfaction with their translation work. The framework of Larson [4] was applied to rate their 
satisfaction with respect to three aspects: the accuracy, the clarity and the naturalness of the translation. The results illustrate that they were dissatisfied with some of the idioms though the texts underwent proofread before publishing. The translators suggested new versions of the unsatisfactory idioms, as did the researcher. The outcome was that the translators found six idioms unnatural, three idioms unclear, and one idiom inaccurate. In addition, the researcher as a reviewer suggested three alternatives to different idioms, apart from the suggestions of the translators themselves; the main reason the researcher suggested other versions was that the renderings in the translations seemed unnatural.

\section{A. The Accuracy of the Translation}

After testing the accuracy of the translation of these two books, only one inaccurate translation was found. The translator of Mr.Maybe found the following idiom inaccurately translated.

Original version - big deal

Translated version -(none)

The translator had to interpret the sentence 'so you ate a lot, big deal' and translated it as 'แค่กินเขอะไปหน่อยเดียวเอง' . At first, the translator meant to retain the sense of satire of the speaker, which showed in the first half of the sentence, but neglected the meaning of 'big deal'. Therefore, the translator wanted to add the translation of big deal as 'ไม่เห็นมีอะไรเลย or 'ไม่เห็นเป็นไรเลย', which were similar to the choices of the researcher.

\section{B. The Clarity of the Translation}

With respect to the aspect of clarity of the translation, three unclear translations of idioms occurred; one in The Trials of Tiffany Trott and the other two in Mr. Maybe.

Original version - barking up the wrong tree Translated version - เล็งผิดคนเว้ย

(The Trials of Tiffany Trott)

What caused the translator to rethink the translation of this idiom was clarity. In this case, the translator wanted to make it clearer that the person whom the characters in the novel were talking about was not the person who they thought was involved in the situation. Therefore, the translator suggested another version: 'คิดผิด' . Nevertheless, the researcher was satisfied with the original translation 'เล็งผิดคนเว้ย' because it seems to render all the meaning of the idiom and was more specific than the revision suggested by the translator in conveying that the characters were all talking about the wrong person.

\section{Original version - Conversation isn't exactly his bag \\ Translated version - พูดเก่งซะที่ไหน}

(Mr. Maybe)

The translator would like to clarify the translated version of this idiom. The translator found that new versions, viz., 'ไม่ใช่คนช่างพูด' or 'ไม่ใช่คนช่างพูดอยู่แล้ว were better in retaining the sense of not letting other people know what that person thinks or feels, which was lost in the published translation. The researcher agreed with the new version.

Original version - getting on your political high horse Translated version - โม้เรื่องการเมือง

(Mr.Maybe)

The translator and the researcher found this idiom improper from the standpoint of clarity, for it was in a conversation of a couple; a new version, such as 'พล่ามเรื่องการเมือง,' would be better when there is a close relationship between the speaker and the listener and it also retains the sense of 'keep on talking'.

\section{The Naturalness of the Translation}

The translations of the books were examined for their naturalness, and six idioms were found to have been translated unnaturally; three were in The Trials of Tiffany Trott and the other three in Mr.Maybe.

Original version - rare bird

Translated version - พันธุ์หายาก

(The Trials of Tiffany Trott)

The translator found this unnatural and suggested the alternative 'แปลกคน' . This new version is more natural than the one in the published translation in her opinion as well as the researcher's.

Original version - spill the beans

Translated version - เปิดเผยเรื่องส่วนตัว

(The Trials of Tiffany Trott)

The translator felt the translated version could be made to sound more natural by repeating the last word as 'ส่วนตั๊ว ส่วนตัว. Thus, the new version was 'เผยเรื่องส่วนตั๊ว ส่วนตัว’ . The researcher agreed with this change because it was not only more natural but also appropriate with the context, which was a conversation between women.

Original version - treat me like a dirt

Translated version - ทำยังกับฉันเป็นเศษธุลีอะไรสักอย่าง

(The Trials of Tiffany Trott)

Naturalness was the reason the translator thought the translation of this idiom should be altered. The translator found her original version unnatural because it was too literal. On this point, the researcher agreed with the translator. An alternative way of translating this idiom is 'ทำอย่างกับไม่เห็นหัวฉัน.

Original version - jumping a bit ahead of yourself

Translated version - คิดมากเกินไป

(Mr.Maybe)

The translator was dissatisfied with the unnaturalness of the Thai translation and suggested another version: 'คิดอะไรเลยเถิดไปกันใหญ่่เล้ว' . The researcher agreed with the translator and suggested as an alternative ‘ตตนไปก่อนไข้,' which the translator had used in translating the same idiom in a 
different context. The researcher made this suggestion in order that the idiom be translated with an idiom, retaining the idiom form in the target language.

Original version - It's not really my neck of the woods Translated version - ผมไม่ค่อยได้มาแถวนี้

(Mr.Maybe)

The translator and the researcher both agreed that the translated version was proper, but it would be more natural to translated it 'ไม่ค่อยชำนาญ/ไม่ค่อยถนัดแถวนี้"

Original version - to fall head over heels in love with you Translated version - ตกหลุมรักเธอแบบถอนตัวไม่ขึ้นแน่

(Mr.Maybe)

The unnaturalness of the Thai translated version was dissatisfactory to both the translator and the researcher. Therefore, 'หัวปักหัวปำ' was suggested as an improvement. The reason for choosing this translation was that, first, it contains is a word meaning 'head.' Another reason was that it is an idiom; though it is not necessary to translate idiom with an idiom, it seems reasonable to do so if possible.

In addition to these, there were some idioms that the researcher found unnatural but the translator did not. Therefore, the researcher as a reviewer would like to suggest another alternative for each idiom.

Original version - let's go Dutch

Translated version - เรามาหารสองกันเถอะ

(The Trials of Tiffany Trott)

The translated version of the idiom the researcher felt was nearly perfect; however, as a Thai, she found a very slightly unnatural use of the Thai language in this case. Normally, in using this idiom, Thais say 'เรามาหารกันเถอะ' without mentioning the number of people. In the context in the novel, there were only two people in the conversation, so the number of people could have been omitted. Nonetheless, the meaning would remain the same in the translator's rendering this idiom by adding the number of people to the translation.

\section{Original version -Happy New Year \\ Translated version - แฮปปี้นิวเยียร์}

(The Trials of Tiffany Trott)

This idiom is a common one. The translator has rendered it properly if considered from the standpoint of accuracy. From the researcher's point of view, however, this idiom has not yet been translated because it is still in the source language though it is written in Thai. Therefore, the researcher suggested 'สวัสดีปีใหม่' the commonly used idiom in the Thai language, as a more natural sounding alternative in the translation.

Original version - ups and downs

Translated version - ดีร้าย
Naturalness was the reason that the researcher suggested another version: 'สุขหรือทุกข์ . The original version was proper in the researcher's view; however, the alternative was suggested because it is more natural, while the meaning remains the same.

It was noticeable that the three suggestions made by the researcher were concerned with the aspect of naturalness. These were very small points, but they deserve attention if one is to create a beautiful and natural translation. This therefore requires a lot of attention on the part of all translators because their task is to retain as much as possible the meaning of the original text when translating it into the target language. In this case, the knowledge of the target language was important. In addition, one original version could also be translated with various alternatives depending on the translator's decision. Different translators may render the same text differently. Therefore, the translator plays a significant role in this aspect.

In testing the translation, the naturalness of the translation depends on the translator's decision as well. As a result, the role of translator is an interesting point that should be further studied in the effort to produce of translation works of good quality.

\section{ACKNOWLEDGMENT}

I would like to thank Institute for Research and Development of Suan Sunandha Rajabhat University's fund for sponsorship.

\section{REFERENCES}

[1] C. Wangsomchok, "An error analysis of English communication of suan sunandha rajabhat university students," in Proc. the VIII International Science Conference, London, pp. 852-856, 2014.

[2] P. Newmark, Approaches to Translation, 2nd ed., Pergamon Press, Oxford, 1982.

[3] X. J. Kennedy, Literature: An Introduction to Fiction, Poetry and Drama, Little Brown and Company, USA, 1983.

[4] L. M. Larson, Meaning-Based Translation: A Guide to Cross-Language Equivalence, University Press of America, Lanham, Maryland, 1984.

[5] C. Fernando, Idioms and Idiomaticity, Oxford University Press, Hong Kong, 1996.

[6] J. Green, Mr Maybe, Penguin Books, London, 1999.

[7] M. Songpao, Mr Maybe Khon Nai Di Phu Chai Khong Chan, 3rd ed., Matichon Publishing House, Bangkok, in Thai, 2004.

[8] I. Wolff, The Trials of Tiffany Trott, Harper Collins Publishers, Glasgow, 1998.

[9] J. Notoda, Tiffany Trott Date Yang Rai Hai Hay Sot, Matichon Publishing House, Bangkok, Thai, 2004.

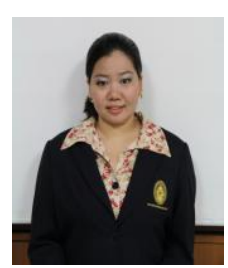

Chinchira Bunchutrakun is a lecturer of Business English Program, Faculty of Humanities and Social Sciences at Suan Sunandha Rajabhat University, Bangkok, 10300 Thailand. 